\title{
The biography of cultures: style, objects and
} agency

Proposal for an interdisciplinary approach

\section{Caroline van Eck, Miguel John Versluys and Pieter ter Keurs}

\section{(2) OpenEdition} Journals

Electronic version

URL: http://journals.openedition.org/cel/275

DOI: $10.4000 /$ cel.275

ISSN: 2262-208X

Publisher

École du Louvre

\section{Electronic reference}

Caroline van Eck, Miguel John Versluys and Pieter ter Keurs, «The biography of cultures: style, objects and agency ", Les Cahiers de l'École du Louvre [Online], 7 | 2015, Online since 01 October 2015,

connection on 17 September 2019. URL : http://journals.openedition.org/cel/275; DOI : 10.4000/cel. 275

\section{(c) (i) () $\Theta$}

Les Cahiers de l'École du Louvre sont mis à disposition selon les termes de la licence Creative Commons Attribution - Pas d'Utilisation Commerciale - Pas de Modification 4.0 International. 


\section{Cahiers de l'École du Louvre}

recherches en histoire de l'art, histoire des civilisations archéologie, anthropologie et muséologie

Numéro 7. Octobre 2015

The biography of cultures: style, objects and agency. Proposal for an interdisciplinary approach. Caroline van Eck, Miguel John Versluys, Pieter ter Keurs

Article disponible en ligne à l'adresse :

http://www.ecoledulouvre.fr/cahiers-de-l-ecole-du-louvre/numero7octobre-2015/vaneck.pdf

Pour citer cet article :

Caroline van Eck, Miguel John Versluys, Pieter ter Keurs, « The biography of cultures: style, objects and agency. Proposal for an interdisciplinary approach. » [en ligne] $n^{\circ} 7$, octobre 2015, p. 2 à 22.

\section{@icreative

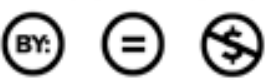

(C) École du Louvre

Cet article est mis à disposition selon les termes de la Licence Creative Commons Attribution - Pas d'utilisation commerciale - Pas de modification 3.0 non transposé. 


\section{Cahiers de l'École du Louvre recherches en histoire de l'art, histoire des civilisations archéologie, anthropologie et muséologie}

\section{Numéro 7. Octobre 2015}

\section{Sommaire}

\section{Éditorial}

\section{Étude}

Caroline van Eck, Miguel John Versluys, Pieter ter Keurs, Leiden University, Departments of Art History, Archaeology, Anthropology/National Museum of Antiquities (résumé et texte intégral en pdf)

The biography of cultures: style, objects and agency. Proposal for an interdisciplinary approach.

\section{Articles}

Camille Bourdiel, ancienne élève de l'École du Louvre, diplômée de $2^{\mathrm{e}}$ cycle (résumé et texte intégral en pdf)

Exposer la science dans l'après-guerre. Hommage à Léonard de Vinci et Rembrandt, étude photographique et radiographique

au laboratoire du musée du Louvre.

Fernando Suárez San Pablo, ancien élève de l'École du Louvre, diplômé de $2^{\mathrm{e}}$ cycle (résumé et texte intégral en pdf)

La politique de restauration

des peintures des musées nationaux (1930-1950).

p. $33-45$

Alexandra Buvignier-Legros, ancienne élève de l'École du Louvre, diplômée de $2^{\mathrm{e}}$ cycle (résumé et texte intégral en pdf)

Pascal Häusermann et le motel L'Eau vive : une conception d'avant-garde? ... p. 46-53

Agnès Gué, ancienne élève de l'École du Louvre, diplômée de $2^{\mathrm{e}}$ cycle (résumé et texte intégral en pdf)

Goya dans l'historiographie française du XIXe siècle : images et textes.

p. $54-63$

Constance Desanti, ancienne élève de l'École du Louvre, diplômée de $2^{\mathrm{e}}$ cycle (résumé et texte intégral en pdf)

Lumière sur Eugène Martial Simas, décorateur oublié de la Belle Époque. ...p. 64-75

Clémentine Delplancq, ancienne élève de l'École du Louvre,

diplômée de $2^{\mathrm{e}}$ cycle (résumé et texte intégral en pdf)

Faire carrière à Paris : Armand Bloch (1866-1932) et la Franche-Comté,

l'importance du soutien régional pour les artistes au XIX" siècle.

p. $76-85$

Claire Merleau-Ponty, consultante en muséologie, (résumé et texte intégral en pdf)

Vous avez dit médiation? p. $86-88$

Andréa Delaplace, ancienne élève de l'EHESS, diplômée de $2^{\mathrm{e}}$ cycle (résumé et texte intégral en pdf)

Un palais pour les immigrés? Le Musée de l'histoire de l'immigration à Paris :

une collection et un musée en devenir.

p. $89-99$

Joan Despéramont, ancienne élève de l'École du Louvre, diplômée de $2^{\mathrm{e}}$ cycle (résumé et texte intégral en pdf)

Les Souffleurs d'images. Un concept développé

par le Centre de Recherche Théâtre-Handicap (CRTH). p. $100-106$ 


\title{
The biography of cultures: style, objects and agency. Proposal for an interdisciplinary approach
}

\section{Caroline van Eck, Miguel John Versluys, Pieter ter Keurs}

\author{
Leiden University, Departments of Art History, Archaeology, \\ Anthropology/National Museum of Antiquities
}

\section{Xu Bing and the agency of demolition debris}

Between 2007 and 2010, the Chinese artist Xu Bing worked on the Phoenix Project. It concerns the creation of two monumental sculptures (each around 100 feet longs and weighing 20 tons in total) displaying both a male and a female Phoenix (fig. 1). Already during the Han dynasty (roughly $200 \mathrm{BC}-$ $A D$ 200) these mythical animals were often portrayed as a pair, and they have been associated with ideas of prosperity, fertility, eternity and imperial power throughout Chinese history. The two birds are fabricated from materials that were taken from construction sites in urban China, including steel beams, tools that were left behind, remnants of the (daily) lives of migrant labourers working on the construction sites and demolition debris. LED lights are installed inside and, when lit at night, these bring out the sculptures' colourfulness and distinct iconography. The phoenixes were displayed outside China for the first time in 2013 in a large hall of MASS MoCA in North Adams (Massachusetts, USA); a modern art museum that is built in a former, 19th-century factory complex ${ }^{1}$.

Xu Bing, Phoenix Project, 2007-2010 metal scrap work, size 90 feet (male phoenix) and 100 feet (female phoenix) as displayed in North Adams, Mass., MASS MoCA in 2013

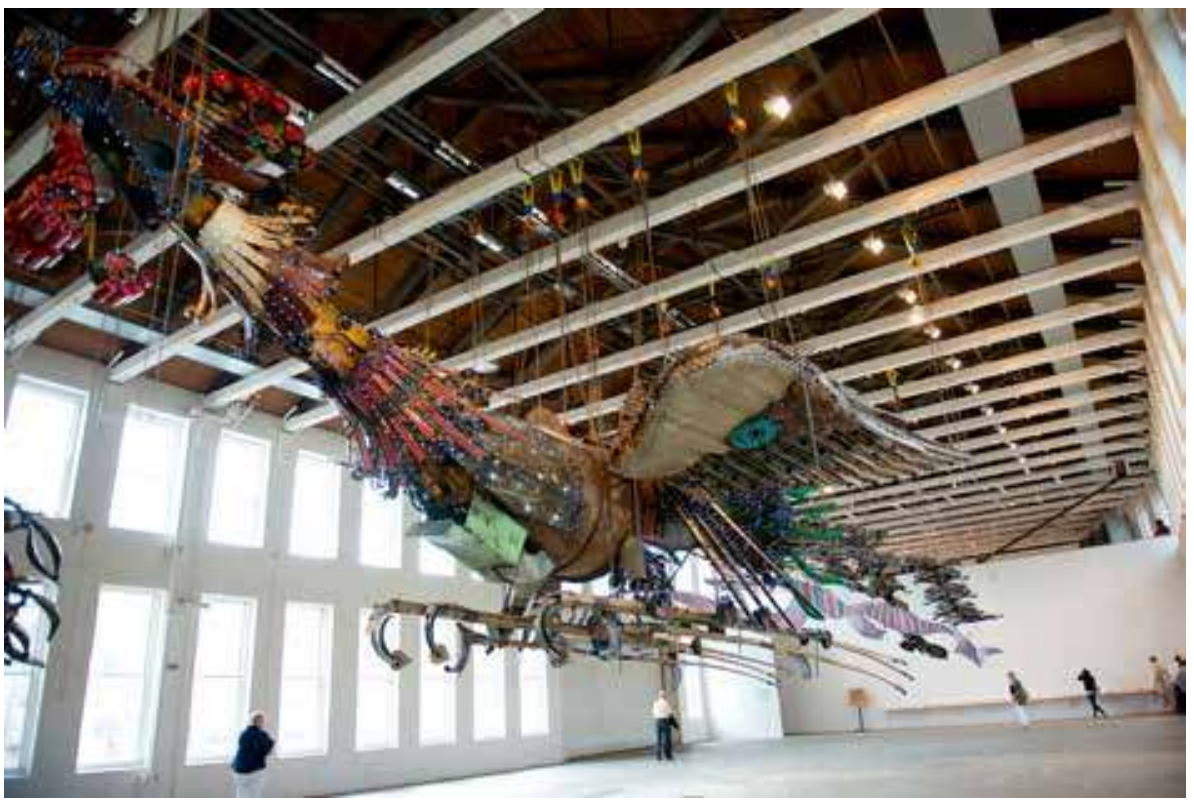

In that context, the material characteristic of the sculptures - namely the fact that they are made up of demolition debris - was said to refer to the history of the building and more generally to the $19^{\text {th }}$-century industrialism of New England.

The authors would like to thank the Leiden University Global Interactions and Diversity Research Profile Area for their financial support, and the participants to the two expert meetings where drafts of this paper were presented for their contributions: Stijn Bussels, Maarten Delbeke, Alexander Geurds, Christian Greco, Mari Hvattum, Sigrid de Jong, Eva Mol, Jo'Anne van Ooijen, Sander Müskens, Alina Payne, Peter Pels, and Thijs Weststeijn. We are grateful to the École du Louvre for their kind invitation to present our research in Paris (12.05.2014) and to publish this paper in their journal.

1. The catalogue accompanying the MASS MoCA exhibition was published by Ouyang Jianghe, Austin Woerner and Xu Bing (2014). The Phoenix Project had been presented earlier in the book by Zhai Yongming, The story of the Phoenix. Xu Bing's Phoenix project (2012). On the work of Xu Bing in general, see the 2008 publication Reading space. The art of Xu Bing. 
Other material characteristics of the sculptures, however, like the red and golden colouring and the specific phoenix-iconography, were clearly signalling "China". But there is more at stake.

The monumental birds were originally designed for a large and impressive steel and glass atrium meant to connect two parts of the World Financial Tower in Beijing. Visiting the building site during his preparations, Xu Bing was shocked by the discrepancy between the working conditions of the (migrant) workers and the luxury of the building itself. He therefore decided to use the debris of their living and working environments to create the sculptures. As Xu Bing explains in the documentary made about the Phoenix Project, it is because the workers held all these things in their hands or wore them on their bodies that, for him, these objects had now become potent witnesses able to communicate the workers' fate. The patron, unsurprisingly, did not like this particular material and the agency accompanying it - and quickly abandoned the project. For his steel and glass atrium he clearly needed different materials with different possibilities of acting on viewers. Xu Bing then decided to continue on his own and, asking the same (migrant) workers who produced the objects to help him make the phoenix sculptures, he developed what is described in the MASS MoCA catalogue as "an artwork almost too vivid in its resemblance to contemporary China". What then is the power of these phoenixes, fabricated from thousands of objects that have no such meaning in themselves; and where, precisely, is this power located?

There is no question about the agency, the (social) effects of the objects as such: they trigger responses about the excess of wealth accumulation in present day China; about bricolage as a strategy of Chinese cultural innovation either good or bad; about the role of labour and capital in Chinese society and about continuities and discontinuities in Chinese history and culture. The very refusal by the patron to exhibit them in their intended setting testifies to these different forms of agency. This is why they were not allowed to take their place in the World Financial Tower but were very welcome in the Today Art Museum in the same city of Beijing. If we try to locate the power of the objects according to the short characterization above, we might conclude that this power and its agency reside in the stylistic and material properties of the objects and their cultural biographies. That they are about China becomes clear from their iconography; this is further enhanced by the red and golden colours used, especially in combination with the LED lightning. That they are, in combination with China, about all those other things (excess of wealth accumulation, bricolage as a cultural strategy, cultural innovation, labour and capital, (dis)continuities in culture and society) as well, is mainly due to the material they are made from and the way in which they are made. A part of their biography, the fact that the phoenixes are fabricated from demolition debris and other objects that carry specific meanings with them thus contributes to their agency because these objects, so to speak, are debris in themselves. Their agency is rooted in their earlier use and meaning. Xu Bing had to use them because he felt they materialized, or externalized, the big issues of contemporary China since they were produced by people living in that context and wrestling with those issues. At the same time, however, we have seen that the earlier meanings that make up the power of the object are not strictly context-dependent or unequivocal. In Massachusetts, USA the objects evoked the industrialism of New England now long gone and, in combination with the statues' aspects that signalled China, the new role of China in the present-day world and its consequences, also for Massachusetts. Therefore, visitors to MASS MoCA will probably have been less concerned with the migrant workers in Beijing who were the point of departure for Xu Bing. Nevertheless the agency of the objects, as determined by their biography of which Xu Bing had now become a part, certainly acted in a similar direction.

In both contexts the objects acted through the iconography of the Phoenix, signalling China, as well as through the properties of the materials used, in this case, through the application of small objects in metal which had already been used, signalling industrialization and modernity. Design and material may support one another. The phoenixes act as a catalyst for all those questions about 
contemporary China because in principle we do not expect a figure from Chinese mythology to look like a modern (European) factory - and because we do not expect it we start contemplating.

This short discussion of Xu Bing's phoenixes serves to introduce the problem we want to present in this article. Although they were made in China, and quite recently, the phoenixes illustrate a problem that is of all times and places. It is evident that artefacts possess agency; but how do they acquire it, and what role does their material and style play in this? Does part of the agency of artefacts consist in their migration from one cultural context to another (as the phoenixes suggest)? If so, what role does a change of cultural context play in the accumulation of the artefact's agency? And, to phrase this question from the perspective of the object: what role then do artefacts play in the constitution and transference of "culture"?

First $(\$ 1)$ we will outline our aims, definitions, research questions and hypotheses.

Then $(\$ 2)$ we will present the problem we want to study in greater depth and argue that our questions necessitate a joint anthropological, archaeological and art-historical approach. We will do so on the basis of a comparison between the presence and agency of "things Greek" in the Augustan and Napoleonic eras. In both periods styles from the past were revived. It is traditionally argued that this happens because of the formal, aesthetic or artistic qualities of these objects. We hope to show, however, that in order to understand the underlying agency of these qualities, it is necessary to study the relative meaning these styles had acquired throughout their cultural biography. The agency displayed by the artefacts significantly determined the decision to revive "the Greek": this truly was a human-thing entanglement. No Renaissances, we argue, can occur without the accompanying objects with their stylistic and material agency. We have chosen to confront the Augustan and the Napoleonic eras, because both periods stand out in terms of the unprecedented availability of artefacts from all over the world and from many (historical) periods. This forced those involved in the appropriation, emulation or creation of artefacts to adopt a position towards their own cultures and the shock of the new, be it in terms of the archaic, the classical or what came to be defined as the primitive. For reasons of consistency we focus on one variety of artefacts, viz. sculpture. To present our problematic, we have chosen two periods in which four styles become the focus of such questioning: "the archaic", "the classical" (most often Greek in appearance), "the Egyptian", and "the primitive" styles.

Both the Augustan and the Napoleonic period constitute an important new chapter in the life of these styles. According to the traditional view the transference of these styles takes place in and through the stylistics or design of individual artefacts: Napoleon imitates the Arch of Constantine in the Arc de Triomphe of the Tuileries, thereby creates the Empire Style, and thus writes another episode in the history of the transference of "the classical". However, as will become clear, the transferences of objects that are seen as related to specific cultures or cultural ideas are not simply motivated by stylistics, at least not when defined traditionally and quite narrowly in terms of artistic qualities or iconographic features. Instead (and underlying these stylistics), in each case the artefact in question creates a presence of something absent (Classical Greece, Imperial Rome, Egypt, the Primitive), acts on the viewer and generates meanings that transcend the narrow confines of iconography or stylistics. We therefore need to look critically at the question of agency and its locus: is Napoleon really making the Empire Style or, to rephrase it quite radically from the perspective this article wants to open up, do Empire Style artefacts in fact help in creating the Napoleonic Empire?

\section{Points of departure; questions and key concepts}

1. Artefacts have the power to create presence, exercise agency and generate meaning. Our first question is: How can we understand that particular power? Anthropological theories looking at what is variously called today the artefact's 
agency, excessiveness, or its power to entangle, are successors to the study of fetishism that started with the work of "desk" anthropologists such as the Président de Brosses ${ }^{2}$. To date Alfred Gell's Art and Agency. An anthropological theory of art (1998), though contested, offers the most substantial theory of the agency of artefacts. In this essay we consider in particular three categories of the artefact's agency: the power of individual artefacts to act emotionally on individual viewers; the power of artefacts to shape the revivals of styles through their historicity; and the agency of artefacts as the basis for culture criticism, identity formation and cultural innovation.

2. Contexts of culture revival are well suited to the study of this power because it manifests itself in a particularly clear fashion in such situations. Our second question therefore is: what roles do the presence, agency and meanings generated by artefacts play in the lives of cultures? Xu Bing's Phoenix exerts such agency that the patron does not want to exhibit it in its original setting, but when transferred to the USA it acquires new meanings, while it still creates the presence of China, though absent, and continues to exert a strong agency on the viewer. The issues identified here have a worldwide relevance, and have become acute to an unprecedented extent in the context of the present wave of globalization (as the $\mathrm{Xu}$ Bing example illustrates). For this essay we will focus on two historical periods that were both revolutionary and saw a remarkable punctuation of connectivity: the era of Augustus and the Napoleonic period. Both periods are Achsenzeiten, periods in which new empires and their canonizations were created and in which artefacts travelled on a hitherto unseen scale ${ }^{3}$. These processes of identity creation and cultural innovation depended on a new positioning towards the past, one's own culture, and the Other, including those cultures that were considered to be outside the realm of civilization and coined as primitive.

3. To understand the power generated by artefacts within the lives of cultures, we start from two aspects of the artefact: its material and materiality on the one hand, and its style on the other. Materiality is understood here as the agency and meaning of the material itself, an essential factor in its power to create presence. One could argue that materiality is related to material just as gender is related to sex: in both cases the former are social and cultural constructions of the latter. Style we understand primarily in the sense of stylistics, that is, of the design, facture, or shaping (in Dutch vormgeving) of the object.

4. We aim to study the transference of culture as a process of the transference of (what we call) culture styles. We can therefore refine and add to our second research question, and ask: what role do artefacts, with their power to act on those involved with it, and to create presence and meaning, play in the transference of culture styles? We define style here in the most basic, factual way: as sets of enduring formal characteristics shared by significant numbers of artefacts. Formal in the sense of the result of the shaping activity of a human hand. Characteristics in the sense of observable traits, resulting from choice ${ }^{4}$. The style of individual artefacts, what we call here their stylistics, and style in the sense of culture style - the Greek, the Roman, the Egyptian, the Chinese, etc. - are different, though related phenomena. The first is a concrete, inherent aspect of artefacts. By the second

2. On excessiveness see Lorraine Daston, "Introduction: Speechless", Things That Talk. Object Lessons from Art and Science, New York, Zone Books, 2004, pp. 9-27; and the essays by Winnicott, Heidegger, and Brown in Fiona Candlin and Raiford Guins eds., The Object Reader, London/New York, Routledge, 2009, which has a very useful bibliography.

3. When mentioning the concept of Achsenzeit we do not want to refer to Karl Jaspers's original ideas so much as to the discussions about canonization and cultural formation they instigated. See the recent and important book edited by Robert N. Bellah and Hans Joas, The Axial Age and its consequences, Cambridge Mass., Belknap Press of Harvard University Press, 2012.

4. Ernst H. Gombrich, "Style", International Encyclopaedia of the Social Sciences, New York, MacMillan/Free Press, 1968, vol. 15, pp. 352-361, recently reprinted in Donald Preziosi ed., The Art of Art History, Oxford, Oxford University Press, 1998, pp. 150-165. For a conceptual analysis of the implicit assumptions at work in Western concepts of style in art history Richard Wollheim's work is still fundamental: "Pictorial Style: Two Views", Berel Lang ed., The Concept of Style, Ithaca, Cornell University Press, 1987; see also Painting as an Art, Princeton, Princeton University Press, 1993, Chapter Two: What the Painter Does; and for a fresh look at the late $18^{\text {th }}$ century developments that led to $19^{\text {th }}$-century codifications of concepts of style see Mari Hvattum, "Zeitgeist, Style and Stimmung: Notes on the historiography of style in the $18^{\text {th }}$ century", Caroline van Eck and Sigrid de Jong eds., The Wiley-Blackwell Companion to Eighteenth-Century Architecture, Boston/Oxford, Wiley/Blackwell, 2015, in press. 
we explicitly do not mean German $19^{\text {th }}$-century concepts of Kulturstile with their value-laden connotations of high culture or Bildung, or early $20^{\text {th }}$-century anthropological notions such as Kulturkreise with explanatory models of diffusion and migration ${ }^{5}$, but sets of common characteristics of material and design shared and displayed by large groups of artefacts, over extended geographical ranges and/ or periods of time.

5. Contrary to traditional views in anthropology, archaeology and art history, however, we do not understand cultures as stable configurations of permanent associations between space, territory, and cultural organization, including style. Much more to the point, in our view, is the point of departure formulated by the anthropologist Maurice Bloch:

"The implications of focusing on the ability of humans to imitate and to borrow information and then to pass it on to another by non-genetic means is genuinely far-reaching. It is what makes culture possible. Since people borrow cultural traits from another, they can individually combine bits and pieces from different individuals. It follows that there are no cultural groups, tribes, peoples, etc ${ }^{6}$."

Central to our project, therefore, is not so much the concept of culture, but that of material-culture ${ }^{7}$. Thus formulated the question of how artefacts can exercise agency, and create presence and meaning in the context of the transference of culture styles becomes a question that only can be answered from a joint, interdisciplinary perspective in which anthropology, archaeology and art history work together.

6. Concepts and theories from these three disciplines will therefore have to be integrated to develop a new theoretical framework to account for these powers of the artefact. Its main feature, we propose, is the biography of the artefact, with its attendant concepts of cultural memory and performance. We have thus chosen to think about the role of artefacts in the transference of style and culture in terms of their biography, which can extend over many centuries and unfold over many countries, from commission, design and its execution to reuse, appropriation, adaptation, destruction, restoration, and its representations in other media, including that of the museum setting. The vitrine is a representational device just as much as drawing, filming or performing a tableau vivant.

Since Gell does not address the role of an artefact's cultural meaning, or the issue of the repetition, reprisal or adaptation of stylistic elements from previous cultures over long periods of time which is a defining aspect of the transference of culture style, his theory of the agency of objects will be combined with Aby Warburg's Mnemosyne theory regarding what he called the Nachleben der Antike. Warburg introduced this vital concept to understand the power of objects to act on those involved, to create presence and meaning, and the transference of culture style. Mnemosyne, for Warburg, is the process of recollection of past art and artefacts, both as an individual artistic process and a feature of shared human memory. The concept of an artefact's biography is therefore complemented, in our analysis, by that of cultural memory and recollection as developed by, amongst others, Aleida and Jan Assmann in the wake of, most importantly, Maurice Halbwachs ${ }^{8}$. Within the transference of style over longer periods of time the artefact functions as the material repository, if not the monument, of the various roles it plays in the situations that together constitute the lifespan of a style.

5. Exemplary in this respect are: Bernard Ankermann, "Kulturkreise und Kulturschichten in Afrika", Zeitschrift für Ethnologie vol. 37, 1905, pp. 54-84 and Fritz Graebner, "Kulturkreise und Kulturschichten in Ozeanien", Zeitschrift für Ethnologie vol. 37, 1905, pp. 28-53.

6. Maurice Bloch, Essays on cultural transmission, Oxford, Berg, 2005, p. 7.

7. Dan Hicks, "The material-cultural turn: event and effect", Dan Hicks, Mary C. Beaudry eds, The Oxford Handbook of Material Culture Studies, Oxford, Oxford University Press, 2010, pp. 25-98.

8. Aleida Assmann, Dietrich Harth eds, Mnemosyne : Formen und Funktionen der kulturellen Erinnerung, Frankfurt am Main, Fischer Taschenbuch Verlag, 1991, Jan Assmann, Das kulturelle Gedächtnis. Schrift, Erinnerung und politische Identität in frühen Hochkulturen Munich,Beck, 1997 [1992]; Aleida Assmann, Erinnerungsraüme: Formen und Wandlungen des kulturellen Gedächtnisses, Munich, C.H. Beck, 1999. 
Cultural memory therefore is considered here on various scales and dimensions, from that of individuals involved with the artefacts to generations or centuries.

7. A further elucidation of the concept of the artefact's biography is that of performance. It will help to solve the problem sketched out above about the relation between the stylistics of individual artefacts and the culture styles with which they are connected. Traditionally artefacts are seen to express, manifest or exemplify a style; or to constitute a style, depending on a nominalist or idealist view of style as existing only in its concrete artefacts or as enjoying a separate, conceptual existence on an ontologically different plane. Such views about the relation between artefacts and their style are problematic for us, because the partners in this relation are unequal: on the one hand a concrete, material artefact, on the other a concept or abstract phenomenon. Circularity and the pitfalls of obscura per obscuriora are dangers here, as $19^{\text {th }}$-century attempts to connect artefacts and style illustrate. Within the context of the transference of styles through artefacts the problem becomes even more acute. When Augustus, for instance, decided to use Egyptian forms or materials, this decision did not automatically imply that he wanted to adopt Egyptian culture. Instead, he used these Egyptian features, we would argue, to create the presence of absent Egyptian culture, that is, its cultural memory in an Augustan, Roman context. To rethink the relation between artefacts and style, and to move beyond the paradigm of the artefact as the concrete, material, but passive expression of that abstract entity, we will draw on the notion of performance, and in particular on recent theories about performance as restored behaviour, which tie in with the Assmanns' concept of ritual coherence as the constitution of cultural memory'. The concept of performance also helps to understand how agency works: when Augustus decided to erect an Egyptian obelisk in Rome, the very performance of that act enabled its agency; and in many respects this performance is more powerful than the mere fact of its standing in Rome. In line with what has been argued above, we would even conclude that it is this performance that also makes Rome. Anthropological literature offers us many examples that support such a conclusion. Rituals are often performed around the incorporation of something that comes from outside, a rare and valuable object or a hunter's prey. These "exotica" are perceived as distinctly foreign on the one hand but simultaneously used to revitalize one's own society on the other. These two aspects are closely related and mediated through rituals (fig. 2). Something that comes from outside is potentially dangerous and has to be ritually 'cooled off to be made into something useful subsequently. Rituals thus clearly renew society with the help of objects from the outside ${ }^{10}$. Performance, we might also say, with its connotations of ritual, is a way of signalling the inherently social character of the agency of artefacts we are interested in: agency is not a static given (in the way iconographic meanings are) but only comes into existence when enacted, that is performed in a social nexus, to use Gell's terms ${ }^{11}$. The third question we want to raise here is therefore: How can we write the biographies of artefacts that together constitute the life of a culture style, drawing on the concepts of cultural memory and performance?

In the seven points above we have outlined our aims, definitions, questions and hypotheses. These all revolve around the three keywords of our title: style, objects and agency. Departing from the fact that world history must be understood as

9. Richard Schechner, Performance Studies: an introduction, New York/London, Routledge, 2002, p. 45 and Marvin Carson, The Haunted Stage: the theatre as memory machine, Ann Arbor, University of Michigan Press, 2001.

10. Ethnographic examples can be found in Cécile Barraud, Jos Platenkamp eds, "Rituals and socio-cosmic order in eastern Indonesian societies", Bijdragen tot de Taal-, Land- en Volkenkunde, I, 145 (4) (1989) and II, 146 (1) (1990) or in Pieter ter Keurs, "Eakalea. A ritual feast on Enggano Island, viewed from a regional perspective", Indonesia and the Malay World, vol. 30, 2002, pp. 238-252. Illuminating historical examples in Meredith Maryin, Daniela Bleichmar eds, Objects in motion in the Early Modern World, Art History vol. 38 (4), 2015. A pertinent analysis of the revitalising role of rituals is presented by Maurice Bloch, Prey into hunter: The politics of religious experience. Cambridge, Cambridge University Press, 1992.

11. Alfred Gell, Art and Agency: an anthropological theory, Oxford, Clarendon Press, 1998, pp. 6-7. 
(an ongoing) human-thing entanglement; we have brought them together in three related research questions:

1. How can we understand the power of artefacts?

2. What roles do the presence, agency and meanings generated by artefacts play in the lives of cultures and the transference of culture styles?

3. How can we write the biographies of artefacts that together constitute the life of a culture style, drawing on the concepts of cultural memory and performance?

Fig. 2

The entry of nakamutmut masked figures in Mandok village, Siassi, Papua New Guinea. Nakamutmut are potentially dangerous mythical figures living in the swamps outside the village, but they also serve to stimulate village, but they also serve to stimulate
fertility. At this occasion, in December fertility. At this occasion, in December
983 , they entered the village to sanction circumcision rituals
(Photograph Pieter ter Keurs, 1983)
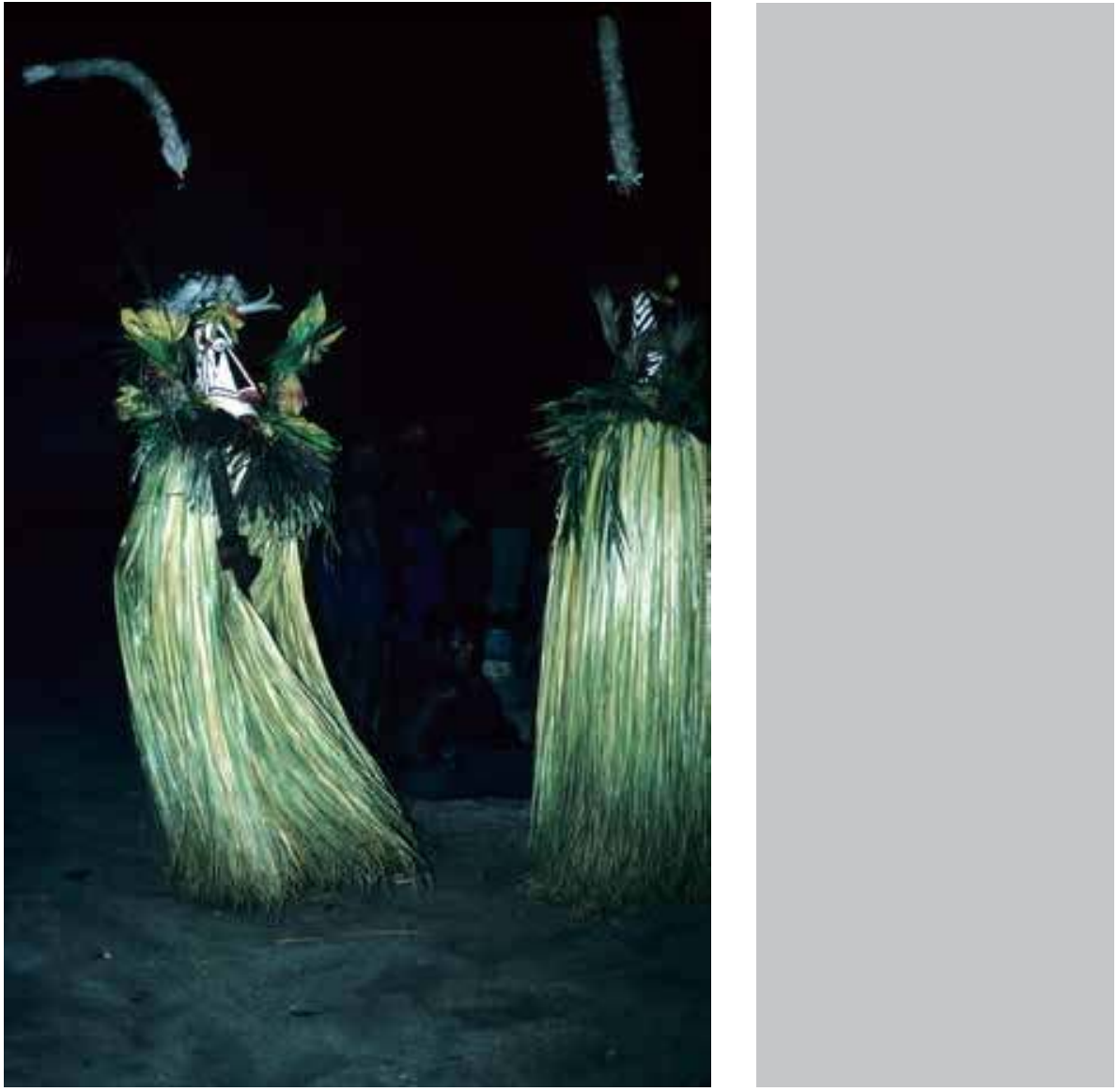

Moreover, we have argued that these questions can only be answered from a joint, interdisciplinary perspective in which anthropology, archaeology and art history work together. By means of a comparison between the presence and agency of "things Greek" in the Augustan and Napoleonic eras we hope, in the next section, not only to illustrate the importance of our questions, but also try to find some historically situated answers.

\section{Transferences in the biography of Greek culture: the materiality and agency of things Greek in the Augustan and Napoleonic period}

This section consists of two parts, one dealing with the Augustan era, the other with the Napoleonic period. We will argue that the (unprecedented) availability, presence and agency of things Greek in those historical contexts determined their (socio-cultural) make-up to a large extent. Both the Augustan and the Napoleonic era are thus "made up", in part, by Greek-looking objects and in particular by the agency that was built up in the course of their lifespan. As we will show, the confrontation with, and appropriation of things Greek necessitated a radical reappraisal of socio-cultural categories like "Self" and "Other", as a consequence of which the concept of what would be called the Primitive (and its agency) had to be rethought. It seems not without reason that in both periods museum contexts 
developed, one could argue to tame the agency of the objects ${ }^{12}$. "Graeciana" had, of course, been exercising their agency in historical contexts before Augustus and would continue to do so until and after Napoleon. Both these periods, however, constitute crucially important new chapters in the life of "Greek culture". Things Greek, therefore, helped in constituting the Augustan and Napoleonic periods, but at the same time the biography of Greek culture could only continue by means of the appropriation, emulation and revival of Greek-looking objects and monuments in those historical contexts. Understanding things Greek in the Augustan and Napoleonic period is thus not so much about the imperial revival of an aesthetically or morally superior style, in our opinion, but about human-thing entanglements resulting from processes of increased connectivity. We will focus here on the object-side of these entanglements and try to explain the particular power and agency of things Greek in terms of style and materiality in the first place.

\subsection{Beyond semantics: materializing the Classical}

In many respects the Augustan era represents one of Antiquity's most profound watersheds and the period has therefore been rightly characterized as witnessing "Rome's cultural revolution"13. All these major changes had been slowly developing over the course of the last two centuries $\mathrm{BC}$ as the result of an ever increasing connectivity of objects and people that characterizes the late Hellenistic world ${ }^{14}$. Through this remarkable punctuation of connectivity there probably now were more objects - from more different backgrounds and areas, and in more different styles - ending up in more different places than ever before in the history of the ancient world. Greek statues that were transported to Rome as booty are therefore part of a much wider development, which is illustrated by the stylistically extremely diverse cargo of the Mahdia shipwreck ${ }^{15}$. In the "globalized" late Hellenistic West European, Mediterranean and Near Eastern oikumene, therefore, material culture now constituted a koine - what has been defined as a "cultural memory bank" in which all kinds of styles and elements were available, from earlier periods too ${ }^{16}$. Places functioning like nodes in the network (such as, for instance, Alexandria, Antioch, Samosata or Rome) show an active appropriation, recontextualization and reworking of all these objects with their various styles ${ }^{17}$. But these cosmopoleis are certainly not unique in revealing

12. For the Napoleonic period this is well known, the clearest case of an attempt to tame the agency of artefacts being the removal of royal tombs from Saint-Denis to the musée des Monuments français by Alexandre Lenoir. This began as an attempt to save these monuments from Revolutionary iconoclasm (in itself a testimony of their agency), but was perceived by contemporaries as a way of domesticating their power to act on viewers by transforming them into aesthetic objects. The art theorist Quatremère de Quincy for instance argued that to remove them from their original setting for the purposes of art history was the ultimate form of iconoclasm: Considérations morales sur la destination des ouvrages de l'art [1815], Paris, Fayard, 1989, p. 48. This attempt at taming the agency of the monuments failed completely. Napoleon wanted to close down the museum because it became a hotbed of royalist sentiment. For the Augustan period this is not so well known but equally true, cf. Steven Rutledge, Ancient Rome as a museum: power, identity and the culture of collecting, Oxford, Oxford University Press, 2012). 13. Andrew Wallace-Hadrill, Rome's cultural revolution, Cambridge/New York, Cambridge University Press, 2008, with all previous literature.

14. Miguel John Versluys, "Material culture and identity in the late Roman Republic (200 BC - 20 BC)", Jane DeRose Evans ed., A companion to the archaeology of the Roman Republic, Chichester, Wiley Blackwell, 2013), pp. 429-440.

15. For the first, see the overview presented in Magrit Pape, Griechische Kunstwerke aus Kriegsbeute und ihre öffentliche Aufstellung in Rom: von der Eroberung von Syrakus bis in augusteische Zeit, dissertation, Hamburg 1975, and the classic paper by Jerome Jordan Pollitt, "The impact of Greek art on Rome", Transactions of the American Philological Association, vol. 108, 1978, pp. 155-174 that starts off with the sentence: "During the sixty-five years from (-) 211 BC to (-) 146 BC the city of Rome was inundated with Greek statues and paintings" (our emphasis); for the latter Gisela Hellenkemper Salies, Das Wrack. Der antike Schiffsfund von Mahdia, Cologne, Rheinland Verlag, 1994.

16. Jas Elsner, "Classicism in Roman art", James I. Porter, Classical pasts. The classical traditions of Greece and Rome, Princeton, Princeton University Press, 2006), pp. 270-297.

17. As can be seen clearly in Alexandrian tombs, cf. Marjorie Susan Venit, Monumental tombs of ancient Alexandria. The theater of the dead, Cambridge/New York, Cambridge University Press, 2002 and, more in general, M. J. Versluys, "Understanding Egypt in Egypt and beyond", in: Laurent Bricault, M. J. Versluys eds., Isis on the Nile. Egyptian gods in Hellenistic and Roman Egypt, conference proceedings, Liège, 27-29 November 2008, Leiden/Boston, Brill, 2010, pp. 7-36. 
the transformative potential of intercultural exchange and the transferences of what we call "Greek", "Egyptian", "Persian", "Italic" etc. culture"

It is on purpose that we use words like "globalized", "oikumene", "koine" and "cosmopoleis" at the outset of a discussion of Augustan material culture because the implications of connectivity in terms of appropriation, emulation and revival are central to its presence and agency. In this period, we should interpret specific iconographies and styles, as Tonio Hölscher has shown so well for things Greek, as part of what he called a semantic system in which specific themes and styles were deemed appropriate for specific subjects and used to evoke specific associations ${ }^{19}$. Traditionally these objects and their stylistic properties were seen as being representative of a culture (that is: passive). Understanding them in Hölscher's sense implies that their stylistic properties signal cultural or socio-economic values and associations within a larger, trans-cultural system ${ }^{20}$. Hölscher's "semantic" system has been (rightly) criticized for both its static character and the fact that it does not really allow for objects to have agency ${ }^{21}$. But his idea of semantics, at least, suggests that stylistic properties were a kind of cultural concept in themselves and were thus active and having an effect on people; this represents an important step forward with regard to traditional iconography and iconology.

How did this Roman language of images function? Answers to this question have so far only dealt with stylistic properties. In what follows we will first discuss that approach, also because it will already prove to be illuminating for understanding the specific agency of objects in the Roman period in relation to their cultural biography ${ }^{22}$. After that, and as a next step, material properties will be drawn into the discussion. Let us start with a definition of Hölscher's semantics:

"For each subject - to be precise, for each thematic aspect within a subject - there were established patterns available, which were of diachronically different origins, but now became synchronically applicable side by side. Thus there arose a system in which the forms of Greek art were filtered, not according to stylistic criteria but primarily according to semantic ones, and could thus now be used with an entirely new meaning. In this sense, one can speak of a semanticisation of the styles ${ }^{23}$."

Within the Roman visual system the stylistic tradition of Hellenistic pathos, for example, was deemed appropriate for battle-scenes, while the stylistic tradition of classical dignity signalled qualities that could be associated with State ceremonial. Specific styles and forms were thus seen as being representative of specific qualities. Formulated from a material culture perspective, this suggests that specific styles and forms were thereby able to express and to evoke specific associations. Thus, dignified gods required the noble forms of high classicism while dancing maenads saw themselves best expressed by the late-5th century BC 'Rich Style'. The style of Lysippos and Praxiteles evoked the qualities associated with noble men, while

18. Tonio Hölscher ed., Gegenwelten zu den Kulturen Griechenland und Roms in der Antike, Munich/Leipzig, Saur, 2000.

19. Idem, Römische Bildsprache als semantisches System, Heidelberg,Winter, 1987), translated into English as The language of images in Roman art, Cambridge/New York, Cambridge University Press, 2004. For the Augustan period specifically, see idem, "Greek styles and Greek art in Augustan Rome. Issues of the present versus records of the past", J.I. Porter, Classical pasts, op. cit. note 16, pp. 237-269.

20. See some remarks in T. Hölscher, "Griechische Formensprache und römisches Wertesystem. Kultureller Transfer in der Dimension der Zeit", in: Thomas W. Gaethgens ed., Künstlerischer Austausch/Artistic exchange, conference proceedings, XXVIII international congress of art history, Berlin, 15-20 July 1992, Berlin, Akademie Verlag, 1993, pp. 67-87.

21. See more extensively M. J. Versluys, "Roman visual material culture as globalising koine", in: Martin Pitts, M. J. Versluys eds., Globalisation and the Roman world. World history, connectivity and material culture, Cambridge/New York, Cambridge University Press, 2015, pp. 141-174.

22. For this aspect see already Annette Haug, "Constituting the past - framing the present. The role of material culture in the Augustan period", Journal of the History of Collections, 13, 2001, pp. 111-123.

23. T. Hölscher, The language of images, op. cit. note 20 p. 86 . See also the remarks by Mark Fullerton, "Description vs. prescription: a semantics of sculptural style", Kim J. Hartswicke and Mary C. Sturgeon eds., STEPHANOS: Studies in Honor of Brunilde S. Ridgway, Philadelphia, University Musum Publications, 1998, pp. 69-77. We will not deal here with the various definitions of "semantics" nor with the (mis)understanding of the term within Classical Archaeology. Within current Anthropology the concept is regarded as superceded. 
satyrs or giants were characterized by the so-called Hellenistic Baroque. Specific styles were thus chosen for specific subjects because they were able to evoke associations connected with those subjects. As such style becomes meaning. This is clear at a glance when we compare two Roman statues of Bacchus, both dating from the second century AD (fig. 3 and fig. 4).
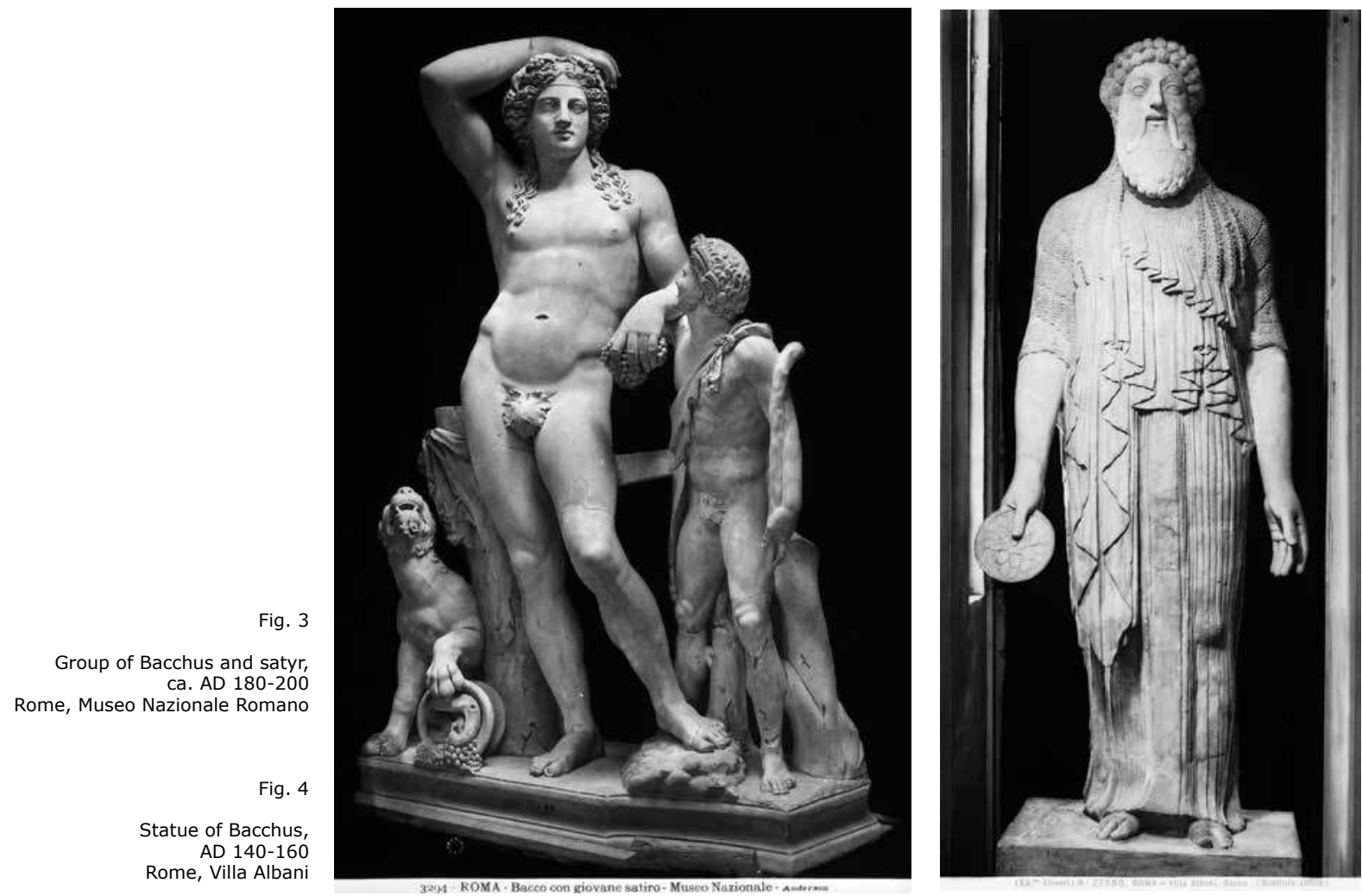

It is clear that these are both representations of Bacchus and in a Greek style, but they are very different kinds of Bacchus. The example in the Museo Nazionale Romano expresses leisure and physical beauty through the Late Classical Style something which is in turn enhanced by the opposing figure of the satyr, who is everything this Bacchus is not. The archaizing style of the Villa Albani example, on the contrary, wants to signal the primitive aspect of the cult of Bacchus ${ }^{24}$. Through their different style and the semantic content associated with those different styles, we may hypothesize that the agency of these statues would have been rather different. So, both statues are Bacchus and both statues are Greek but they only possess their specific meaning because of their specific style and the qualities or properties accompanying that semantic association. And they will only acquire their specific meaning through repeated performances in varying contexts. It follows that, in terms of agency, different themes and styles will have acted on both the context in which they were displayed and their viewers in rather different ways. It is in this domain that, in order to accommodate our research questions, Hölscher's ideas have to be elaborated upon. His model is fundamentally about style and meaning while we would like to discuss style and agency. In fact Hölscher resumes the classical rhetorical concept of style as the most apt, fitting and persuasive way of expressing something, whether in word or visual form. He thereby bypasses the problem of the confusion of the linguistic and the textual that has dogged so many (post-) structuralist varieties of anthropological or archaeological research ${ }^{25}$. Rewriting the history of the

24. Nele Hackländer, Der archaistische Dionysos. Eine archäologische Untersuchung zur Bedeutung archaistischer Kunst in hellenistischer und römischer Zeit, Frankfurt, P. Lang, 1996. 25. As illustrated by, e.g., Lambros Malafouris, "The cognitive basis of material engagement: where brain, body and culture conflate", Elizabeth DeMarrais, Chris Gosden \& Colin Renfrew eds, Rethinking Materiality. The engagement of mind with the material world, Cambridge, McDonald Institute for Archaeological Research, 2004, pp. 53-62; and argued by Bjørnar Olsen, In Defense of Things. Archaeology and the Ontology of Objects, Lanham, Altamira Press, 2010, pp. 40-42. 
formation, identification and conceptualization, during Antiquity, of styles and stylistic elements in terms of material agency is thus of crucial importance.

\subsection{Cultural biographies of things Greek}

Both the Late Classical Style Bacchus and the archaizing Bacchus were clearly referring back. Above it was suggested that their agency consisted of their style and the associations thus evoked. And because these styles made (different) references to the past we may thus hypothesize that this agency was grounded in the cultural memory of the Hellenistic oikumene ${ }^{26}$. Styles, in other words, seem to have been able to "bundle" cultural memory and thus to transpose meaning from one context and historical period to another. It is thus the cultural biography of a specific element and its style that become the locus of its agency in a specific historical context. In this respect there is something like "the inherence of the prototype" in the sense of the ongoing presence of the original appearance of these types of divine images in subsequent version ${ }^{27}$. But it is equally important to pay attention to the successive stages - or performances - following from this prototype and radically altering it. At the same time this agency is built up, growing and developing through the historical contexts in which it is functioning. Objects with their stylistic properties, in other words, acquire agency throughout their life. And it seems logical to assume that when they live longer, and when they therefore are part of increasingly diverse historical contexts with their human-thing entanglements, their agency grows stronger.

Styles and elements of the Mediterranean and Near Eastern past thus logically formed an important part of the Augustan cultural memory bank. It seems, therefore, that Hellenistic koine is an "anachronistic Renaissance" almost by definition $^{28}$. The Augustan period proves to be such an important watershed because it was during this period that specific choices from this koine were made and these choices were to form the canon that we call Roman visual material culture. The Augustan period is thus about the canonization of large parts of Mediterranean and Near Eastern history and, with that, of Hellenistic koine ${ }^{29}$. It is, in fact, as a result of the persisting Augustan focus on Greece and things Greek that we talk about Greco-Roman Antiquity as if there were a logical development from classical Athens to imperial Rome. In fact, of course, this was a Roman "invented tradition" with a lot of material culture to back up the claim; and it would prove to be a very successful one ${ }^{30}$. We might therefore expect the period around "The Year One" to be a fundamental crossroads of thought about material culture, antiquity, style and the agency of artefacts ${ }^{31}$. We have seen that in Hölscher's understanding of Roman visual material culture both (iconographical) theme and style play an important role; and that he focuses almost exclusively on things (looking) Greek. In order properly to understand, however, Augustan Rome as a transformative context of intercultural encounters we propose first to

26. For such processes more in general, and again with a focus on (material culture as) text, see J.I.Porter, Classical pasts, op. cit. note 16.

27. Robert Maniura, Rupert Shepherd eds., The inherence of the prototype within images and other objects, Aldershot, Ashgate, 2006; for Antiquity and the Augustan period more specifically, see M. Fullerton, "Der Stil der Nachahmer: A Brief Historiography of Stylistic Retrospection", in: Alice A. Donohue, M. Fullerton eds., Ancient Art and its Historiography, Cambridge/New York, Cambridge University Press, 2003, pp. 92-117.

28. Alexander Nagel, Christopher S. Wood, Anachronic Renaissance, New York, Zone Books, 2010, pp. 29-35. Their distinction of performative and substitutive varieties of anachronism is particularly suggestive in the context of this essay.

29. See in general Elaine Gazda ed., The Ancient Art of emulation: studies in artistic originality and tradition from the present to classical antiquity, Ann Arbor, Mich. : Published for the American Academy in Rome by University of Michigan Press, 2002 and more specifically the important volume by Michela Fuchs, In hoc etiam genere Graeciae nihil cedamus. Studien zur Romanisierung der späthellenistische Kunst im 1. Jh. v. Chr., Mainz am Rhein, P. von Zabern, 1999.

30. See Dietrich Boschung, Alexandra Busch, Miguel John Versluys eds., Reinventing "The Invention of Tradition"? Indigenous pasts and the Roman present, Paderborn, Wilhelm Fink, 2015 (Morphomata 32)

31. Even from a global perspective, cf. the exhibition catalogue edited by Elizabeth J. Milleker, The Year One. Art of the ancient world East and West, exh. cat., Metropolitan Museum, New York, 2001, NewHaven/London, Yale University Press, 2000. 
focus on more than Greece alone (Egypt, the Oriental, the Primitive) and second to add materiality to the picture ${ }^{32}$.

Here we can only deal briefly with the first aspect. Recent research has made it abundantly clear that the presence and agency of things Egyptian, for instance, made itself strongly felt in Augustan Rome, far beyond notions of the conquered Other alone. Obelisks, for instance, were taken from Egypt to Rome and soon developed into the supreme symbol of Roman imperial power - with both their distinct stylistic and material properties playing an important role through their cultural biography ${ }^{33}$. With Egyptian objects also came ideas that had become attached to them in earlier phases of their biography, for example ancient/venerable, exotic and religious. These associations played a role with their appropriation in the Augustan context as well.

Questions about the presence and agency of "the Primitive", to give another example, are as important as they are underexplored. We know that people from the North (Celts, Germans and Scythians) were made to function as "the Primitive" in Roman perception; scholars have even talked about "Borealism" in this context ${ }^{34}$. But was there also a category of "primitive art" for the Romans? As Arthur Lovejoy already showed in his fundamental study of primitivist thought in antiquity, the primitive has always been defined in the West as the opposite of the classical. But how this actually worked in the visual arts in the Augustan period, and how the actual confrontation with artefacts from the borders of the empire influenced such ideas, needs to be investigated ${ }^{35}$. A complicating factor with these questions is that, for instance, "the Celts" had become part of the Hellenistic world from the period of around $200 \mathrm{BC}$ onwards and that hence there does not seem to have been really something like a Celtic culture style with its own and distinct stylistic and material properties as is the case with Greek, Egyptian, etc. ${ }^{36}$. At the same time, however, the agency of objects we call Celtic certainly was strong in the societies in which they functioned; this will in turn have influenced the Romans ${ }^{37}$.

\subsection{Beyond representation: style and material as agency in the Augustan period}

Materiality, understood as the awareness of the significance and agency of the material itself, as distinguished from its representational content or meaning, plays an important part in the power of languages of images ${ }^{38}$. Augustus was, as far as we know, the first Roman leader to use original statues from earlier periods as cult statues. Statues from the Classical and Archaic period occupied a central place, for instance, in the temple for Apollo on the Palatine. Pliny (NH 36, 24/5, 32) mentions an Apollo statue made by Skopas, an Artemis made

32. Joseph Maran, Philipp W. Stockhammer eds., Materiality and Social Practice. Transformative capacities of intercultural encounters, Oxford, Oxbow Books, 2012.

33. M. J. Versluys, "Egypt as Part of the Roman Koine: Mnemohistory and the Iseum Campense in Rome", in: Joachim Quack, Christian Witschel eds., Religious flows in the Roman Empire (Orientalische Religionen in der Antike), Tübingen, Mohr Siebeck, 2014 (in press) and, idem, "Haunting traditions. The (material) presence of Egypt in the Roman world", Boschung, Busch, M. J. Versluys eds., Reinventing. The invention of tradition? op. cit. note 31, pp. 127-158.

34. Christopher B. Krebs, "Borealism: Caesar, Seneca, Tacitus and the Roman discourse about the Germanic North", Erich S. Gruen ed., Cultural identity in the ancient Mediterranean, (Los Angeles, Getty Research Institute, 2011, pp. 202-221.

35. Arthur O. Lovejoy and George Boas, Primitivism and Related Ideas in Antiquity, Baltimore, Johns Hopkins Press, 1935.

36. Felix Müller, Die Kunst der Kelten, Munich, Beck, 2012, Ch. IV.

37. See the exhibition catalogue edited by F. Müller, Art of the Celts. $700 B C$ to $A D 700$, Antwerp/ London, Mercatorfonds/Thames \& Hudson, 2009, also on the question of the existence of a distinct Celtic style and, with attention for material agency, Duncan Garrow, Chris Gosden, Technologies of enchantment? Exploring Celtic art: $400 B C-A D$ 100, Oxford, Oxford University Press, 2012. 38. To combine the titles of the English translations of the two German classics in this domain: Paul Zanker, Augustus und die Macht der Bilder, Munich, Beck, 1987, translated into English as The power of images in the age of Augustus, Ann Arbor, Mich., University of Michigan Press, 1990 and T. Hölscher, Römische Bildsprache, op. cit. note 20, translated into English as The language of images in Roman art, op. cit. note 20. 
by Timotheos and a Leto from Kephisodotos ${ }^{39}$. Where earlier monarchs, such as Caesar or Pompey, had only copied earlier prototypes or styles in order to suggest a relationship to the past, Augustus now added their materiality as well ${ }^{40}$. There certainly was canonization here in stylistic terms: Augustus was keen to display what were characterized as masterpieces in the art-theoretical debates of his time. But it was not, as is often thought, on the categories of the "classical" alone that he capitalized ${ }^{41}$. Augustus also displayed archaic statues - perhaps even in the fronton of the Apollo temple (Pliny, NH 36, 13). So, it is clear that stylistic properties mattered because, through their cultural biography, they were able to trigger specific associations. As such they had agency: "Die klassischen Formen hoben das dargestellte Geschehen in einen auratischen Raum, der die gewünschten Vorstellungen hervorrufen sollte" 42 . In this vein an archaic/hieratic form or style signalled "religious" in an Augustan context; while "classical" was not only that which was evaluated as the summum of artistic perfection of the past but also the akme that was now being surpassed. This clearly is about the representational aspect or meaning of objects with their stylistic properties ${ }^{43}$. But there simultaneously is an awareness of the significance and agency of the material. The fact that Etruscan or Italic statues were made out of tuffa (bricks) suggested and stressed archaism, and therefore religiosity in an Augustan context. At the same time, the fact that Augustan temples now were made out of marble and not out of tuffa anymore made clear that the "old times" were over and that it was Rome that had become classical in its own right. The well-known passage from the Res Gestae that reads "I found Rome a city of brick and left it a city of marble" must be read in this light, as becomes perfectly clear from a (later) remark by Suetonius, who says: "Rome was originally not decorated pro maiestate imperii, but was improved by Augustus so fundamentally that he could rightly praise himself: he found her brick but left her marble. ${ }^{44 "}$ So, not only stylistic properties came with specific associations and thus agency, material properties did as well: marble is pro maiestate imperii. The example of the Augustan use and appropriation of marble makes this particularly clear: scholars have even talked about a truly "Augustan marble revolution". It is through this revolution that associations were now established between (specific colours of) marble and specific themes or figures ${ }^{45}$. This symbolism, or, in other words, the canonization of the Augustan period, would strongly influence what came after. In this aspect the Augustan period is a major watershed as well: through processes of increased connectivity, marble now came to play a major role in the Mediterranean and Near East. Undoubtedly meant to illustrate Roman "world domination" initially, this human-thing entanglement of the Augustan period would soon come to stand for Rome itself. And marble did much more than signalling Roman imperialism alone, especially in combination with stylistic properties. Scisto verde, for instance, could be used with an archaic or classical style to give the impression of old, weathered bronze: style and material were enhancing each other in order to make the presence and agency of the object as strong as possible.

39. See P. Zanker, "Klassizismus und Archaismus. Zur Formensprache der neuen Kultur", in: Kaiser Augustus und die verlorene Republik, exh. cat., Berlin, 1988, Mainz am Rhein, von Zabern, 1998 , pp. $622-35$ and compare for another important context in this respect, Eugenio la Rocca, "Der Apollo-Sosianus-Tempel", Kaiser Augustus und die verlorene Republik, pp. 121-136.

40. P. Zanker, Augustus, op. cit. note 38, p. 242: "Dem klassischen Original scheint man also über den Kunstwert hinaus eine besondere sakrale Aura zugesprochen zu haben". In general, see still the useful historical overview by Hans Jucker, Vom Verhältnis der Römer zur bildenden Kunst der Griechen, Frankfurt am Main, V. Klostermann, 1950.

41. For Augustan classicism, see still P. Zanker, Klassizistische Statuen. Studien zur Veränderung des Kunstgeschmacks in die römischen Kaiserzeit, Mainz am Rhein, P. von Zabern, 1974 and Hellmut Flashar ed., Le classicisme à Rome aux I ${ }^{\text {ers }}$ siècles avant et après J. -C., Geneva, Fondation Hardt, 1978 as well as Karl Galinsky, "Augustan Classicism. The Greco-Roman synthesis", ibidem, pp. 180-203.

42. P. Zanker, Augustus, op. cit. note 38, p. 252. I think that the use of the word "auratischen"/"aura" is meant here, and in the earlier quotation, to indicate what we now call agency.

43. See in general Mark Fullerton, The archaistic style in Roman statuary, Leiden/New York, Brill, 1990.

44. Suetonius, Vita Augusti, 28.

45. See the important work by Rolf Michael Schneider, Bunte barbaren. Orientalstatuen aus farbigen Marmor in der römischen Repräsentationskunst, Worms, Werner, 1986, especially Chapter 4 and, idem, "Coloured marble. The splendour and power of imperial Rome", Apollo. The international magazine of the arts, 154 (473), 2001, pp. 3-10, with the qualification "Augustan marble revolution" on pp. 3-4. 
It is difficult to come closer to the agency of objects in Augustan Rome by means of viewer responses. There are many literary sources from the Roman imperial period showing (although often indirectly) that "the animated image" was, though often perceived as problematical, "the default mode" of thinking about the agency of objects, especially statues ${ }^{46}$. However, there are few surviving viewer responses dealing with the specific agency of specific stylistic and material properties $^{47}$. Would the agency of the Villa Albani Bacchus have been stronger if the statue had been made out of wood? Was there a difference, in terms of agency, between a painted tuffa statue of a god and a similar statue in painted marble? We cannot tell on the basis of literary sources, but a close study of the way objects functioned in their religious or political context might help. We hope to have shown, however briefly, that relations between material agency, the cultural biography of objects, their performance in a specific context and the constitutive role of objects in the transference of cultures were clearly felt in the Roman era. Questions of material agency mattered as much to Augustus as they mattered to $\mathrm{Xu}$ Bing, and as we shall see, to Napoleon. It is also for that reason that Rome would prove to be such a decisive phase in the biography of Greek culture and Greek culture style.

\subsection{A statue that refuses to be tamed}

As in the Augustan age, the years from 1795 to 1815 saw an unprecedented increase in the availability of artefacts in Europe, arriving from all over the world, from Egypt to the Pacific. As a result of the wars between revolutionary France and the rest of Europe, thousands of European artworks and exotic art artefacts, from Germany, the Netherlands, Austria, Italy, and Egypt, were taken from their original settings, where there was often limited access to them, and began to migrate across the Continent, to end up in Paris. This immense increase in connectivity forced those involved in these migrations of artefacts to ask fundamental questions about how they defined art, what it meant to transport artefacts from religious settings into the secular context of the museum, and how to deal with exotic artefacts. If these last were exhibited in the Louvre, this would imply that they were granted the status of artworks. Housing them in the Muséum of the Jardin des Plantes would present them as ethnographica. Placing them in the Bibliothèque Nationale would implicitly mean denying them the privileged status they possessed because of their striking visual and material characteristics, and instead considering them as antiquarian objects. Our confrontation with this period in this section therefore also serves to underline the necessity for a joint anthropological, archaeological and art historical approach in both cases. The questions we ask about Canova's Victorious Venus are ones that we also need to ask about the Villa Albani Bacchus; and vice versa.

In 1804 Prince Camillo Borghese asked the sculptor Antonio Canova to make a statue of his wife Pauline, Napoleon's favourite sister. The result, finished in 1808, was a life-size portrait of Pauline reclining naked on a bed, represented as Venere Vincitrice, Venus victorious (fig. 5): she holds the apple that Paris gave her when asked to choose the most beautiful goddess. It is one of the first statues of this size representing a living woman, and a very public figure as well, naked, and as a goddess. In fact it is a horizontal version of the Venus of Arles, itself a Roman copy made in the Augustan period of a statue, now lost, by Praxiteles ${ }^{48}$. Canova's statue is thus the third episode in the cultural biography of an object that began life in 360 BC. It was shown to the public for the first time in 1809, in the

46. See the recent monograph by Stijn Bussels, The animated image. Roman theory on naturalism, vivedness and divine power, Berlin/Leiden, Akademie Verlag, 2012.

47. See, however, the interesting observations in J. I. Porter, "Philodemus on material difference", Cronache Ercolanesi, 19, 1989, pp. 149-178. This important topic is in need of further exploration, as already becomes clear from Martial. Ep. VIII, 55 (on the lioness associations of marmor Numidicum) or Lucianus, The Hall. Bettina Reitz, Building in Words: Representations of the Process of Construction in Latin Literature, PhD thesis, Leiden, 2013, presents many sources that deal with what we call materiality.

48. Alain Pasquier and Jean-Luc Martinez, Praxitèle. Un maître de la sculpture antique, exh. cat., Louvre, 2007, Paris, Louvre/Somogy, 2007. 
Palazzo Chiablese in Turin, where the Prince at this time held court, as governor of Piedmont appointed by his brother-in-law ${ }^{49}$.

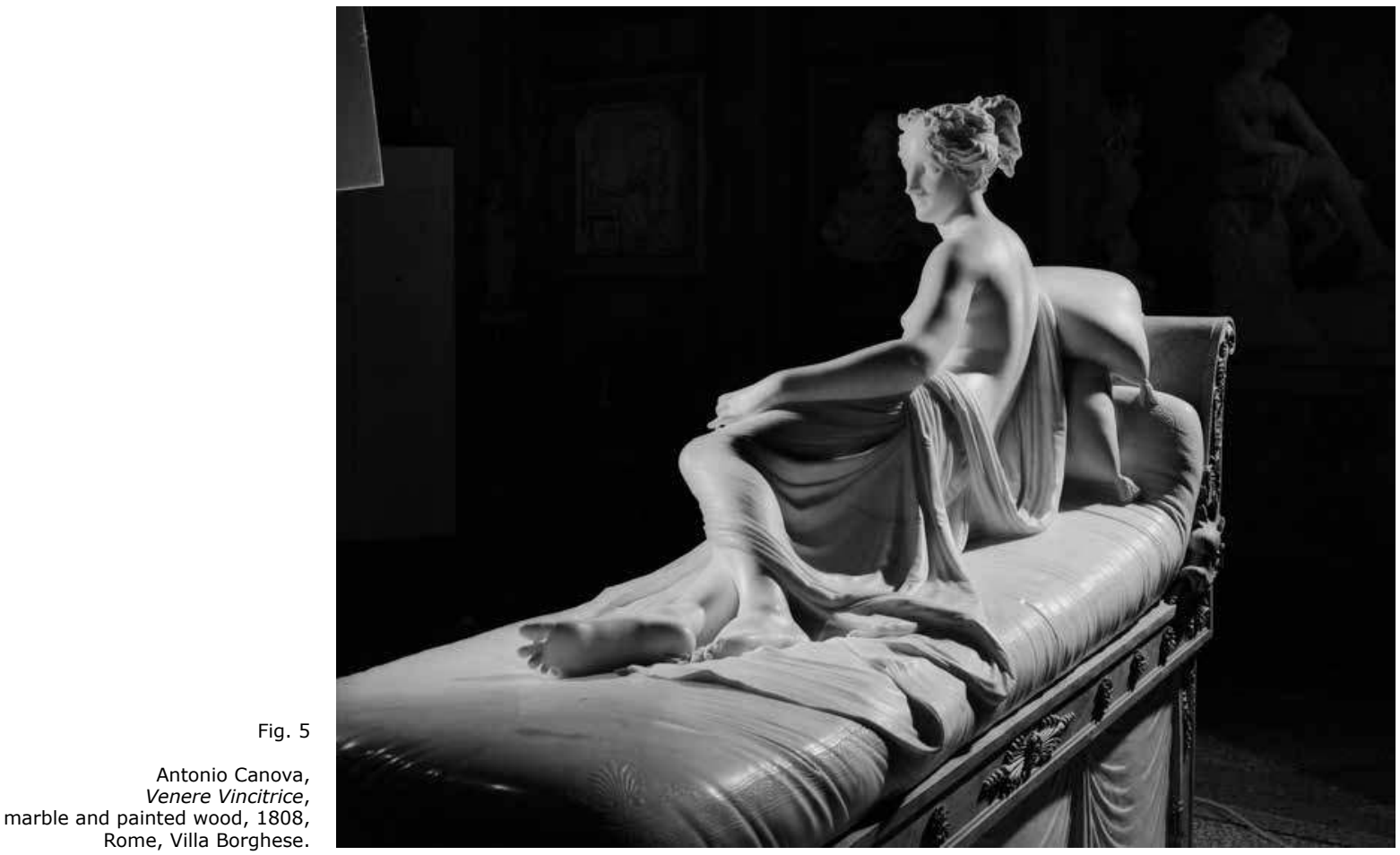

From the moment the Venere Vincitrice was shown, its material presence became an issue. The beauty of the model, the pose, the nudity, and the fact that Pauline Borghese had posed naked for Canova were already sufficient to attract a crowd. But the extreme virtuosity of Canova's treatment of the body of the goddess and in particular his ability to suggest the softness and lustre of living skin also made the statue a celebrity.

Both Canova's biographer Melchior Missirini and his friend, the ci-devant commissioner for the preservation of French dynastic art, museologist and art theorist Antoine-Chrysostome Quatremère de Quincy, reported on the crowds that came to gaze at the statue at night, illuminated by torches, to appreciate, as Canova himself also claimed, much better than by daylight "le gradazione della carnagione", the rendering of the living and breathing body ${ }^{50}$.

These nocturnal viewings of Pauline Borghese as Venus were part of the fashion for looking at statues by torchlight that had originated in late $18^{\text {th }}$-century Rome, where it had been propagated at the Villa Albani. They culminated in the nocturnal visits by Napoleon and his court to the newly arrived Laocoon (fig. 6) in the Musée Napoléon ${ }^{51}$. Usually these nocturnal viewings are considered simply as a passing fashion in sculpture viewing. But in their staging of statues at night, in a torch-lit room, for a selected audience, they came very close to transforming sculpture viewing into a theatrical, performative event. This new episode in the

49. For a more extended treatment of the reception of this statue and the issues it raises see Caroline A. van Eck, "Works of Art that Refuse to Behave: Agency, Excess and Material Presence in Canova and Manet", to appear in New Literary History.

50. Melchior Missirini, Della Vita di Antonio Canova Libri Quattro, Prato, Giachetti, 1824, Book II, Chapter 4, p. 189; Antoine-Chrysostome Quatremère de Quincy, Canova et ses ouvrages, ou, mémoires historiques sur la vie et les ouvrages du célèbre artiste, Paris, A. Le Clerc et cie, 1834, pp. 147-149, and Antonio Canova : lettre à Vivant Denon, Rome, 2 April 1811, A 117.55, Biblioteca nazionale, Rome, quoted in Pascal Griener, «Le Génie et le théoricien. Canova selon Quatremère de Quincy», Pascal Griener and Peter J. Schneemann, eds., Images de l'artiste Künstlerbilder, Bern, Peter Lang, 1998, pp. 149-160.

51. See Jon J.L. Whiteley, "Light and Shade in French Neo-Classicism", Burlington Magazine, 117, nr 873, 1975, pp. 768-773; Christopher J. Wright, "The <Spectre> of Science, the Study of Optical Phenomena and the Romantic Imagination. Journal of the Warburg and the Courtauld Institutes,Dies war Schrift/Pitch 3,13* - Ein. 43, 1980, pp. 186-200; Claudia Mattos, "The Torch Light Visit", Res : Anthropology and Aesthetics, 49/50, 2006, pp. 139-150 ; and Susanne Küchler, "Malangan: Objects, Sacrifice and the Production of Memory", American Ethnologist, 15/4, 1988, pp. 625-637 for the anthropological ramifications of this phenomenon. 
cultural biography of the Praxitelean naked Venus thus acquired a performative character that equals the intensity of the revival of classical sculpture in Augustan Rome.

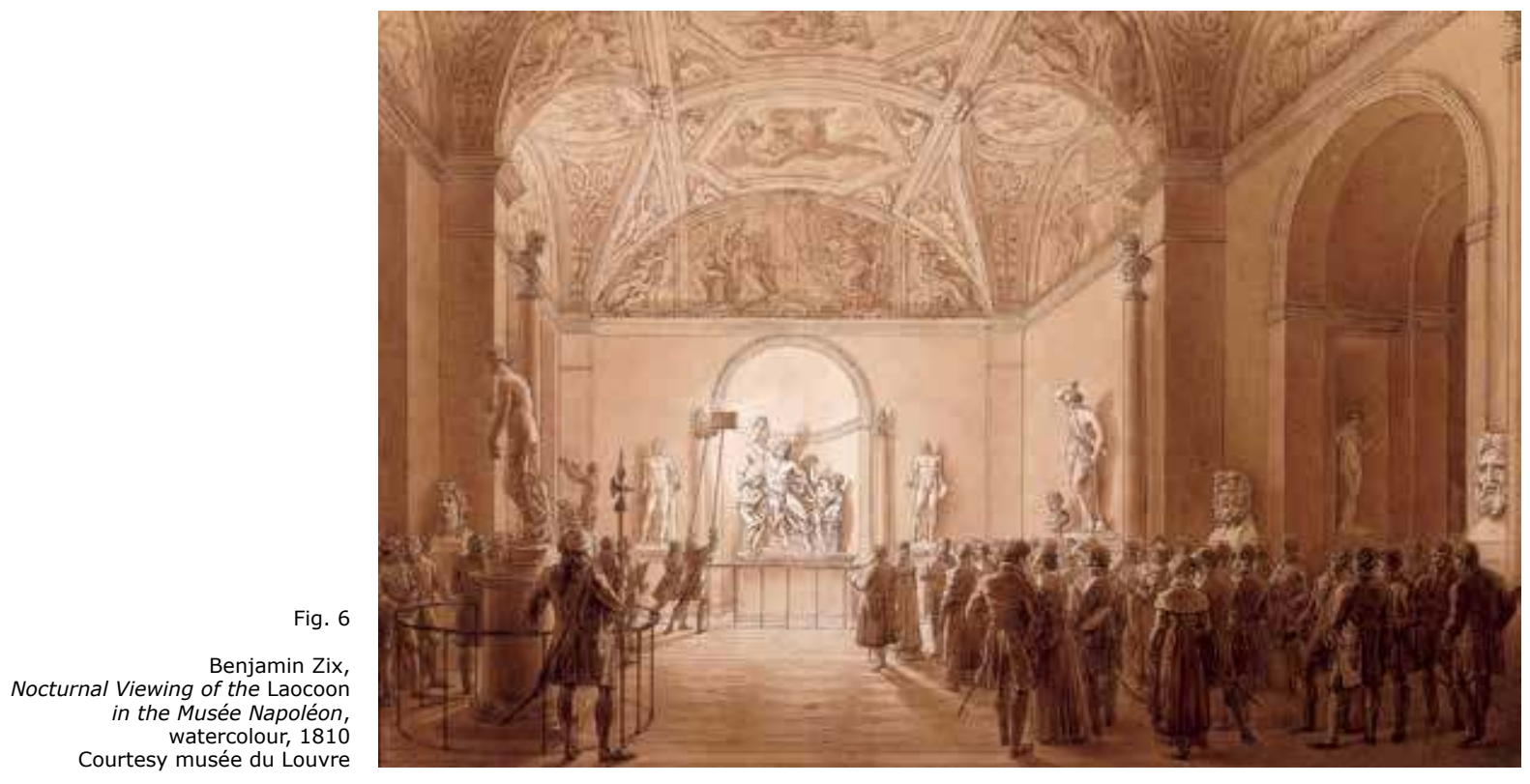

The French diarist Joseph Joubert observed how under such viewing conditions in the flickering light statues seem to move towards the viewer from the dark. The play of light on the marble suggests living skin, and "ces formes idéales et molles dont les corps animés semblent comme environnés [apparaissent] à chaque trait

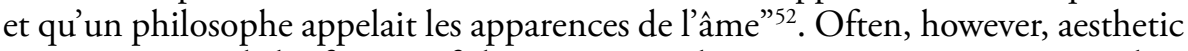
appreciation and the frisson of the uncanny, when inanimate stone appeared to be a living and sentient body, gave way to far less elevated sentiments among the viewers, and eventually the Princess Borghese would ask her husband to remove her statue from public viewing. After its removal to Rome the Prince put the statue in a specially constructed wooden cage, whose keys he personally kept. In the 1830s the Pope, his vicar and the Canova family were still so uneasy about the indecency of the pose and the reactions it caused that one of Canova's inheritors asked the engraver Domenico Marchetti to make a new version of his etching of the Venere Vincitrice, this time with veils added to cover her naked torso (fig. 7 and fig. 8$)^{53}$.

Another feature added to the presence, agency and suggestiveness of this statue: its genesis. As mentioned, Pauline Borghese had posed naked for the sculptor. When asked how she felt about this, she famously replied, "Well, the room was heated" 54 . But the fact that Canova had made a moulage à vif of her body added to its scandalous character. In itself the use of a mould made on the living body of the model to serve as the plaster model for the statue was considered slightly disreputable, because it was felt to be a sign of poor craftsmanship on the sculptor's part, as in the famous allegations of moulage à vif when the Elgin Marbles were first shown to the public ${ }^{55}$. But there was also a whiff of scandal because of the intimacy it implied between the sculptor and his model. Neo-classicist art theorists rejected such procedures because the result would be too naturalistic,

52. Joseph Joubert, Essais (1779-1821), Rémy Tessonneau ed., Paris, A.G. Nizet, 1983, p. 45. See also Joseph Joubert, Les carnets de Joseph Joubert, André Beaunier and André Bellessort eds, Paris, Gallimard, 1938, vol. II, pp. 573, 748.

53. Hugh Honour, "Canova e l'incisione", in: Grazia Pezzini Bernini and Fabio Fiorani, eds, Canova e l'incisione, Bassano del Grappa, Rome and Bassano, Ghedina \& Tassotti, 1994, pp. 11-21; Kristina Herrmann-Fiore, "Lettere inedite sulla statua di Paolina", Canova e la Venere Vincitrice, Anna Coliva and Fernando Mazzocca, eds, exh. cat., Rome, 2007, Milan, Electa, 2007.

54. Flora Fraser, Venus of Empire: the life of Pauline Borghese, London, A\&C Black, 2012, p. 109. 55. See for instance William Hazlitt's defence of the marbles against these accusations in his essays On the Elgin Marbles: the Ilissus (originally published in the London Magazine of February 1822 ) and its sequel On the Elgin Marbles (London Magazine of May 1822), reprinted in William Hazlitt, The Fight and Other Writings, Tom Paulin and David Chandler eds, London, Penguin, 2000, pp. 212-238, in particular pp. 213-217. 
and thereby excite base feelings in the viewers ${ }^{56}$. Such a moulage also went against the idealist view of the sculptor's act, extending as far back as Michelangelo's famous formula that the sculptor liberates the form hidden in the marble. Here, on the contrary, the intellectual aspect of sculptural disegno was obscured by the very material act of moulding her body ${ }^{57}$.

Fig. 7
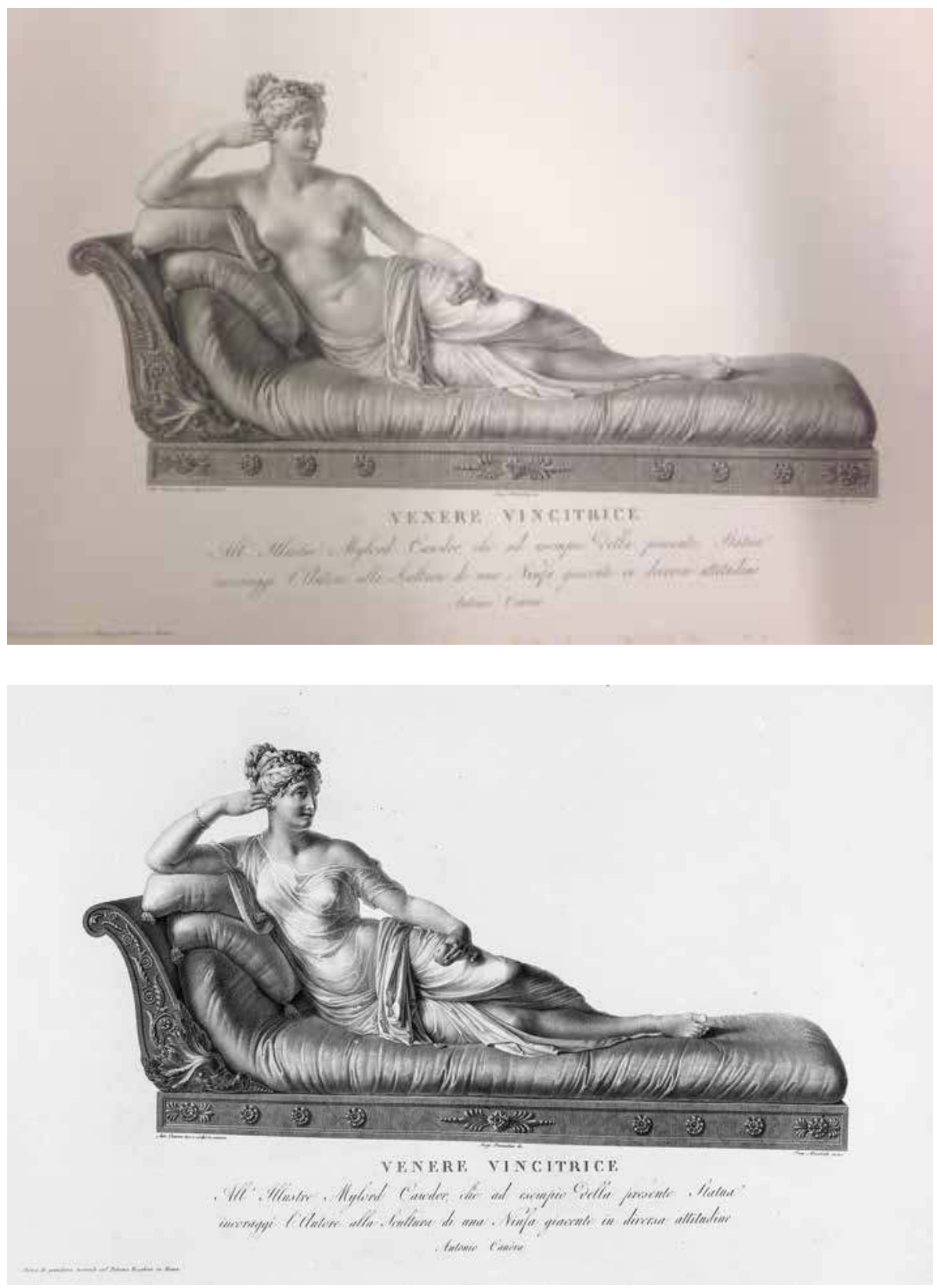

For the purposes of our enquiry Quatremère's reaction was the most telling. He particularly praised Canova's capacity to transform matter. Under his hands, the marble is made to suggest a living and breathing body, and the wooden bed is disguised as a marble couch. Quatremère called this the characteristic of high art, that sets the statuary of Phidias or Praxiteles apart from the fetishes of "primitive" people: an aesthetic distance resulting from a use of materials that marks the difference between the living being represented and its representation ${ }^{58}$. But here the sculptor's transformation of his materials by means of its very virtuosity almost topples over into its opposite. The presence and agency of the

56. Tom Flynn, The Body in Three Dimensions, New York, Abrams, 1998, pp. 115-122.

57. Maria Anna Flecken, "Und es ist Canova, die sie machte", Hildesheim, Olms, 2008, pp. 92136 for the genesis of the statue.

58. Antoine-Chrysostome Quatremère de Quincy, Le Jupiter Olympien, Paris, de Bure, 1815, pp. XXIII and 2. 
statue could not be tamed by aesthetic distancing, and in the eyes of the viewers who could not refrain from touching it, it became its opposite, a statue that is so lifelike it appears to be animated. Another aspect is also significant here: the decision to adopt the pose of the naked victorious Venus. Somewhat later, Pauline's brother Napoleon would adopt the position of the god Mars in another full-length naked statue by Canova. Both cases were scandalous precisely because of what they set out to achieve: to create the Empire Style as a conscious attempt to revive the Roman Empire, but with new protagonists. Pauline's statue was the more successful of the two. It came to act as a powerful, though somewhat unruly, material embodiment of cultural memory, adding, as many observers noted, a new chapter to the biography of the Praxitelian Venus, by its pose to the sister of the French Emperor: une grande horizontale praxitélienne, one might be tempted to call the statue.

Yet at the same time, and here we can begin to ask new questions that are seldom asked in art history, the impact of the statue was very different from what the patron or the sculptor intended. By its presence and effect on viewers, and the cultural meanings associated with its design - its materiality in short - it far transcended a mere revival of the forms of Greek sculpture of the classical period. As Quatremère's reaction documents, the statue also posed serious aesthetic and museological issues by its refusal, one might be tempted to say, to respect the boundaries of representational distancing. By that very refusal, and in particular by its origin in moulage à vif, it can be connected with another issue that was very present in the same period: that of fetishism.

In the $19^{\text {th }}$ century treating artworks as living beings increasingly became dismissed from the range of acceptable behaviour. Art theorists rejected it as an unaesthetic attitude that denied the representational character of art and disrupted disinterested enjoyment of the formal or stylistic properties of artworks. Historians of religion and ethnographers from the 1750s onwards, including De Brosses, Guasco and Dulaure, after having labelled such behaviour among non-Western art viewers as fetishism, increasingly also included such behaviour by Western viewers under the same label ${ }^{59}$.

Canova's statue of Pauline Borghese was thus created at the very moment when ethnographic studies of fetishism began to include Western religious and artistic practice, when aesthetic disinterested enjoyment became the dominant mode of art viewing in the recently founded museum at the Louvre, and the ideals of enargeia as embodied in classical sculpture were again, but perhaps more anxiously than ever before, held up as a model for Empire art. Its reception also shows very clearly how the statue's excessive power to create presence, act on viewers and suggest all sorts of meaning could not really be accommodated. This had to be prevented by taking measures usually reserved for living beings: being locked up out of sight (the husband's reaction) or having a veil thrown over her naked torso (as in Marchetti's revised etching, made at the request of the Canova family). Alternatively, its agency was denied by stressing the representational virtuosity of the sculptor (Quatremère's strategy), or reduced to a mere image (Missirini's museological treatment). It thus offers the perplexing case of a statue that by its very design and materiality acted very strongly on viewers, became a main actor in the renewal of the classical style, and thus a major embodiment of cultural memory, in fact one of the main dynastic icons of the new Empire Style. Yet at the same time its agency refused to be tamed. The sheer physical presence of the statue, even now, far outweighs the dynastic concerns from which it originated.

\subsection{Material presence and the primitive}

With the rise of ethnography, at about the same time when Pauline Borghese's statue was locked up, it became standard practice to tame the sometimes

59. On this development see Caroline van Eck, François Lemée et la statue de Louis XIV sur la Place des Victoires à Paris. les débuts d'une réflexion ethnographique et esthétique sur le fétichisme, Paris, Éditions de la Maison des sciences de I’homme, 2013. 
frightening power of ethnographic objects. Scholarly classifications gave the objects their places in "neutral" systems of thought and the power of the physical presence of objects was often defused by placing them, isolated from their original ritual context, in museum showcases or storerooms in the newly founded public museums ${ }^{60}$. The dangerous and strange power of African and Oceanic objects was neutralized behind glass or firmly placed out of view in inaccessible storerooms, as happened for instance with the statues of war gods from the Pacific made of millions of birds' feathers and dogs' teeth that reached Paris and London in the late $18^{\text {th }}$ century, brought back from the voyages of James Cook $^{61}$. The material presence and agency of artefacts could be a shock, because they excited feelings normally associated with living beings, such as fear in the case of African masks or desire and love in the case of the Venus Borghese. Such disruptions, however, could also be desired for their power to suggest the presence of an absent past or an absent "far-away".

This occurred, as we have seen, around 1800, a period that should be characterized as a crossroads in Western thought about art, antiquity and the agency of artefacts. All those new ideas were fuelled, if not instigated, so it seems, by an unprecedented increase in the availability of artefacts. The same situation seems to have occurred around "the year 1"; although for the Augustan era the evidence available allowing us to talk about a fundamental crossroads is both different and more circumstantial. Our presentation of the relations between objects, style and agency in the Augustan and Napoleonic periods respects and follows both the limitations and possibilities of the available sources. For the Augustan era we therefore presented the large outlines that enable us to discuss the relation between, for instance, Greek statues and Roman identity or the different effect of an archaic Bacchus in comparison to a classical Dionysos. But we lack the viewer responses and detailed historical contextualization which we do have for Canova's Victorious Venus. In her case, however, it was exactly the richness of source material that seems to have obstructed these broader, anthropological questions on the formation of cultures and culture styles.

Augustan Rome and Napoleonic Paris both show us crucially important chapters in the biographies of the archaic, the classical, the Egyptian and the primitive. The confrontation in itself is therefore highly illuminating, since during both periods similar questions and problems were met with and had to be solved. Around 1800 traditional modes of thought about the agency of artefacts under the headings of idolatry and iconoclasm were challenged by the new disciplines of anthropology and ethnography. They showed that the attribution of agency to objects that goes beyond their material properties is a universal feature of human societies. Developments in the Augustan era have hardly been conceptualized in these terms; although they seem highly relevant ${ }^{62}$. In both periods it is the conquest of Egypt that triggers an unprecedented opening up of horizons, and forces those involved to take a position towards what was previously rejected as the primitive. The parallels between these two situations have hardly been explored $^{63}$. As Rome seemed to change into "a new Memphis" in the Augustan Age $^{64}$, Napoleon's ambitions with the Louvre were meant to present Paris as the successor to Athens and Rome.

\footnotetext{
60. See Tony Bennett, The Birth of the Museum. History, Theory, Politics, New York, Routledge, 1995.

61. See for instance the statue of the Pacific war god Kuka'ilimoku, which entered the French royal collection before 1789, now on show in the Louvre, and the observations by Frances Connelly on the coincidence of the arrival in Paris of such statues from the Pacific and the return to classical taste at the Académie Royale de Peinture: Frances Connelly, The Sleep of Reason. Primitivism in Modern European Art and Aesthetics, 1725-1907, University Park, The Pennsylvania State University Press, 1999, p. 26.

62. Greg Woolf, Tales of the Barbarians. Ethnography and Empire in the Roman West, Malden, Mass/Oxford, Wiley-Blackwell, 2011.

63. On the Napoleonic expedition to Egypt as a major constituent of the Empire Style, see Bonaparte et l'Égypte. Feu et lumières, Jean-Marcel Humbert dir., exh. cat., Paris, 2008-2009, Arras, 2009, Paris, Hazan, 2008, pp. 272-298.

64. M. J. Versluys, "A new Memphis", (Preface to) Giuseppina Capriotti Vittozzi, La terra del Nilo sulle sponde del Tevere (Collana di studi di egittologia e civiltà copta I) Rome, Aracne, 2013, pp. 13-17.
} 
Around 1800 a shift occurs in the locus for discussions of the power of artefacts to be present, exercise agency and generate meaning that cannot be understood in isolation from its materiality. It moves from the realm of classical sculpture (or Western religious art in a wider sense), to the non-Western sphere of fetishism, that is of the primitive ${ }^{65}$. The primitive is implicitly present in both of our case studies. Our analysis of the Augustan cultural revolution strongly suggests similar shifts. In both the Augustan and Napoleonic periods, the confrontation and sometimes interaction of culture styles (the Hellenistic/Imperial koinè, le Empire Style) with the primitive serves as the furnace that generates awareness of the agency artefacts can exercise. For the Augustan Age, this is virtually unexplored territory; more work has been done on primitivism in the $18^{\text {th }}$ century, but there is no systematic study of the actual reception, by those who took part in primitivist debates, of the artefacts that were called primitive.

Anthropology, archaeology and art history, the three disciplines that study the artefact, are all concerned with style, objects and agency, but use these concepts in different ways, to different purposes, and as a part of different historiographical contexts.

In this essay we have argued that the agency of the artefact is unmistakeable, unavoidable, and often untameable. To understand this fully, its role in the transference of culture styles must be investigated. This we can only do by combining the three disciplines that, from their foundation in the $18^{\text {th }}$ century onwards, have taken the artefact as their object of study. If we adopt the perspective of the artefact's agency as central to our concern, and if we take the various examples presented in this article as illustrations, we identify three aspects of the transference of culture styles that need further study. In each of them the three disciplines meet:

1. Style formation. Cultures manifest themselves in artefacts that share a number of clearly recognizable material and visual characteristics. Artefacts create meaning and exercise agency in the social networks which they help constitute. Individual artefacts act on individual viewers, as in the case of the Venus Borghese, but there are also more complex varieties of agency in which groups of artefacts are appropriated to develop the historicity of a new empire, as in the case of classicizing statues in Augustan Rome; or objects can question, by their very material presence, the ways a culture has developed to tame agency, as in the case of the African masks in museum showcases. This is an anthropological reformulation of the problem of culture style transference.

2. The biography of the artefact. The cultural biography of the artefact is the material nucleus of culture transference. Artefacts serve as the material manifestation of a culture, and their survival, adoption, adaptation, appropriation or transformation over the years is what constitutes the transference of a culture style. We take the biography of an object thus quite literally, drawing on the Gellian concept of personhood, to understand the agency of artefacts in the succeeding episodes of their lives ${ }^{66}$. Here archaeology and anthropology meet to consider a phenomenon that until now was mainly treated by art historians.

3. The formation, survival and renewal of cultural memory in its material manifestation. Whereas cultural memory is often conceived as ritual and textual coherence, we add material coherence. Drawing on recent theories of performance as the mediation of cultural memory and restored action, the formation of cultural memory can be studied as a series of ritual enactments of coherence that can take place in all kinds of settings or media. One can think of Roman

65. For an analysis of the primitive in Western Art, see Ernst Gombrich, The preference for the Primitive. Episodes in the History of Western Taste and Art, London/New York, Phaidon, 2002 and F. Connelly, The Sleep of Reason, op. cit. note 61.

66. A. Gell, op. cit. note 12, pp. 5, 66 and 96. 
Imperial rituals and their early modern revivals in triumphal arches or joyous entries or of moving obelisks around in Rome and giving them a new, (Augustan or Papal) setting and thereby a new material coherence. From this perspective the presentations of museum collections, despite their apparently static character, are also performative mediations of cultural memory. In all these performances new interactions between the artefact and the creator, viewer or user are created in which the agency of the artefact plays an important role and can deploy itself. Here art history meets anthropology to look at what used to be an archaeological topic, the discovery, revival, restoration and exhibition of material remains from past and distant cultures. What we aim to provide, therefore, is a historical account of the development of material agency.

\section{Les auteurs}

Caroline van Eck is Professor of History and Theory of Architecture and Visual Art to 1800, and will be Slade Professor of Fine Art in Oxford in 2017. As a chercheur invitée at the École du Louvre in 2013 she organized the colloquium "Les idoles entrent au musée: la sculpture, son historiographie, sa muséographie 1660-1850", whose paper will be published by the École in 2016. Recent publications include Art, Agency and Living Presence: From the Animated Image to the Excessive Object (Munich and Leiden 2015).

Miguel John Versluys is associate Professor of Classical \& Mediterranean Archaeology at the Faculty of Archaeology from Leiden University. His research focuses on cultural interaction in the ancient Mediterranean, Egypt and the Near East. He recently co-edited the CUP volume "Globalisation and the Roman world. World history, connectivity and material culture". Together with Caroline van Eck and Pieter ter Keurs, he is the founder of the Leiden "Material Agency Forum”.

Pieter ter Keurs is in charge of the Department of Collections and Research of the National Museum of Antiquities (Rijksmuseum van Oudheden) in Leiden, Netherlands. He is trained as an anthropologist and did fieldwork in Papua New Guinea and Indonesia. His Ph.D. was on the relationship between objects and subjects. Current research interests are "agency and material culture' and 'history of museums and collections". Ter Keurs is also Professor of Anthropology of Material Culture at Leiden University. 